\title{
The Effectiveness of Waste Crude Bromelain Pineapple and Papaya Fruit Mixture as Anti-Plaque Toothpaste
}

\author{
Authors \\ Ratnaningsih DA ${ }^{1}$, Subiyandono ${ }^{2}$, Sri Wahyuni ${ }^{3}$ \\ ${ }^{1,2}$ Department of Pharmacy, Minister of Health Polytechnic Palembang, Indonesia \\ ${ }^{3}$ Department of Dental Nursing, Minister of Health Polytechnic Palembang, Indonesia \\ Corresponding Author \\ Ratnaningsih DA \\ Email: ratnaningsih_plg@yahoo.co.id
}

\begin{abstract}
Background: Several studies have shown that excessive use of fluoride toothpaste can cause bone loss, kidney problems, decreased IQ and gastric disorders, especially in children.

Objectives: This study aims to make preparations of excellent and stable toothpaste from the combination of coarse waste bromelain pineapple (Ananas comosus L. Merr var Quin) and papain rind of papaya (Carica papaya $L)$ as well as to examine the effect as an anti-plaque toothpaste.

Methods: The toothpaste obtained was tested for 28 days regarding physical stability including $\mathrm{pH}$, viscosity, foam height, homogenous, color, smell, and taste. The effectiveness of the antiplaque dentifrice preparations was tested on 25 volunteers for seven days.

Results: The results showed that for the physical stability $\mathrm{pH}$, viscosity, homogeneity, high foam, color, and smell meets the requirements and preparation do not irritate the skin. ANOVA statistical test $(p<0.05)$ showed that there was a significant difference between the average deviation of plaque score group toothpaste containing a combination of bromelain and papain. But at Posthoc Test, the average difference of toothpaste plaque score group showed no significant difference

Conclusions: It can be concluded that the toothpaste containing a combination of bromelain and papain meet the requirements of the physical stability and affect the effectiveness of anti-plaque toothpaste with the most efficient combination is $4.25 \%: 0.75 \%$.
\end{abstract}

Keywords: Toothpaste, waste pineapple, bromelain, papain, Score Plaque.

\section{Introduction}

Caries or tooth decay is a disease of the oral cavity caused by bacterial destruction activity against dental hard tissue (email, dentin, and cementum). This damage if not treated immediately will soon spread and extend to all gears. According to data from the Household Health Survey in 2007, the prevalence of dental caries attack Indonesia's population reached $76.92 \%$.

Many efforts should be made to prevent dental caries, such as by applying tooth brushing habits to reduce the duration of contact with the teeth leftovers. That requires anti-plaque ingredient in toothpaste. The anti-plaque material most widely used is Flurida. This content has been shown to be 
effective to prevent the recurrence of dental caries. The amount of fluoride in oral hygiene preparations must not exceed $0.15 \%$. One must look for another anti-plaque ingredient in safer toothpaste such as using enzymes digestive of plants. The use of enzymes in toothpaste is intended to help the breakdown of proteins, carbohydrates, and lipids in the leftovers.

Proteolytic enzyme is one of the groups of enzymes that catalyze the hydrolysis reaction of digestive peptide bond that links the amino acid to the polypeptide chains. Examples of proteolytic enzymes are pancreatic enzymes such as trypsin and chymotrypsin, bromelain, (proteolytic enzymes from pineapple plants) and papain (a proteolytic enzyme from papaya plants). The use of the enzyme bromelain and papain as an antiplaque has been proven by several studies as toothpaste or mouthwash.

According to Harmely, Lucida and Mukhtar (2011), stem bromelain from pineapple at levels of $5 \%$ is useful as an anti-plaque toothpaste. Research by the same formula has been done by Rahmadini (2013) in formulating rough bromelain from pineapple hump in toothpaste and testing their physical stability for 28 days. Meanwhile, according to Waluyatrie (2011), mouth rinses enzyme papain $0.1 \%$ and $0.2 \%$ can reduce the number of colonies of bacteria Streptococcus $\alpha$, but does not reduce the growth of plaque in children aged 13 to 15 years.

Apart from the fruit, stems, and tubers, crude bromelain may be obtained from other parts of the pineapple fruit, such as crowns and skin. All parts of the section together with the stems and tubers waste after pineapple is consumed directly or canned. These residues may reach $30-40 \%$ of the total fruit pineapple fruit consumed (Diapari, 1997). Utilization of waste as a source of enzyme bromelain pineapple is an alternative to overcome the impact of debris on the environment. According to Charlena, Girinda, and Rifani (2009), in $25 \mathrm{ml}$ of crude extract obtained 168.18 mg waste pineapple enzyme bromelain.

Along with it, the enzyme papain found in all parts of the plant papaya(Carica papaya L) such as fruit, stems, petioles and leaves. The content of the sap of the results leads papain in papaya fruit skin is $10 \%$ (Winarno, 1995).

Papain is already used as an active ingredient in toothpaste. In addition to anti-plaque as well as bleach (whitening) to staining of the teeth caused by smoking, coffee or tea beverages by breaking the glycoprotein and lipoprotein bond of salivary fluid and bind calcium salts that form the basis of teeth staining. Applications of enzyme papain whitening toothpaste have been already on the market with activity levels of $0.1-1 \%$ in $6000 \mathrm{U} /$ mg. Safety gear after use of papain has been investigated by Lopes (2007).

Based on the data above arises a thought to formulate a gel toothpaste with an anti-plaque combination of bromelain enzyme produced from waste pineapple and papain enzyme from papaya fruit skin. It is expected that this research is being an alternative for the utilization of waste generated by pineapple abundant in South Sumatra.

The method used for testing anti-plaque is plaque control recording method introduced by O'Leary et al. and is used to monitor the control of plaque in patients and also in many dental clinics. For the first measurement, tooth plaque is colored with dyes (disclosing solution, gel disclosing or disclosing tablets) were recorded is whether or not the deposit stained on dentongingiva limit on four surfaces (Dalimunthe, 2008).

\section{Materials and Methods}

This study was an experimental study on the use of waste bromelain pineapple (Ananascomosus $L$. Merr var Quin) and papain rind of papaya (Carica papaya $L$ ) as an anti-plaque toothpaste. Research design used was randomized pretest-posttest control group design. Research object is bromelin coarse varieties of pineapple waste quin and enzyme of papain which is tapped directly from papaya aged 2.5-3 months. The subjects were students from the Department of Dental Nursing voluntarily willing to use toothpaste during the study by filling out forms and sign a statement as a volunteer. Before the first treatment to 
volunteers explained the purpose of research and other information relating to the use of toothpaste. To assess the state of dental plaque, dental examination before and after the application of toothpaste was made by the researcher who is also a dentist. This study used five volunteers for each formula toothpaste so to 5 groups of 25 volunteers are employed. Used tools are an analytical balance, glass tools laboratory standards, mortar and stamper, glass mouth. Other necessary materials are wastes of pineapple, young papaya fruit still in the tree, ammonium sulfate, phosphate buffer $\mathrm{pH} 7,96 \%$ ethanol, dental plaque disclosing gel (Global care), quads, Na CMC, Calcium Carbonate, Glycerin, Natriumlauril sulfate, $\mathrm{Na}$ saccharin, methyl paraben, propyl paraben and peppermint oil. Finally, waste pineapple (crown, bark, stems, and tubers) mashed with a homogenizer is then filtrated.

On days 1 to 7 volunteers using toothpaste studied doses of researchers determined. On day 8 was repeated measurements of plaque index scores by providing dental plaque disclosing gel. The plaque index scores were measured by comparing the number of total plaque score divided by the number of tooth surfaces was examined.
In this study, a clinical examination on the plaque is determined by the plaque index modification by Turesky of Quigley-Hein criteria, where:

Code 0: means no plaques

Code 1: there are patches of plaque separating cervical margin of teeth

Code 2: there is a thin layer of continuous plaque in the cervical area of no more than $1 \mathrm{~mm}$

Code 3: there is a layer of plaque more than 1 $\mathrm{mm}$ but cover less than a third of the tooth crown Code 4: plaque covering between one-third to two-thirds of the tooth crown

Code 5: plaque includes more than two-thirds of the tooth crown

The results are presented in the form of tables and histograms and will be analyzed with the theory of pharmaceutical as well as the statistical test a one-way ANOVA ( $\mathrm{p}<0.05)$.

\section{Results}

Rough bromelain obtained from the pineapple waste consisting of the crown, fruit skins, stems, and tubers. $19.356 \mathrm{~kg}$ of waste obtained $39.31 \mathrm{~g}$ bromelain rough yielding extraction of $0.238 \%$. Meanwhile, $95.6 \mathrm{~g}$ of papaya fruit sap is tapped and rough papain obtained is $9.7 \mathrm{~g}$. The papain yield is roughly $10.15 \%$.

Table 1 Results of physical examination on waste pineapple bromelain

\begin{tabular}{|c|c|c|c|c|c|}
\hline \multirow{2}{*}{ No. } & \multirow{2}{*}{$\begin{array}{c}\text { Type of } \\
\text { Examination }\end{array}$} & \multicolumn{2}{|c|}{ Bromelain } & \multicolumn{2}{|c|}{ Papain } \\
\hline & & Observations & Standards & Observations & Standards \\
\hline 1. & $\begin{array}{l}\text { The critical } \\
\text { apparatus }\end{array}$ & $\begin{array}{l}\text { yellowish- } \\
\text { white powder, } \\
\text { specific odor }\end{array}$ & $\begin{array}{c}\text { white powder } \\
\text { color to yellowish } \\
\text { with a distinctive } \\
\text { odor }\end{array}$ & $\begin{array}{c}\text { white powder } \\
\text { color with a } \\
\text { distinctive smell }\end{array}$ & $\begin{array}{c}\text { powder, amorphous or } \\
\text { somewhat grainy white } \\
\text { to light brown, distinct } \\
\text { scent }\end{array}$ \\
\hline 2. & $\begin{array}{l}\text { The degree of } \\
\text { acidity }(\mathrm{pH})\end{array}$ & 7.0 & $6-8$ & 6.8 & $6-7$ \\
\hline 3. & solubility & $\begin{array}{c}\text { soluble in } \\
\text { water forming } \\
\text { a colloidal and } \\
\text { insoluble in } \\
\text { ethanol }\end{array}$ & $\begin{array}{c}\text { soluble in water } \\
\text { forming a } \\
\text { colloidal and } \\
\text { insoluble in } \\
\text { ethanol }\end{array}$ & $\begin{array}{c}\text { partially soluble } \\
\text { in water and } \\
\text { practically } \\
\text { insoluble in } \\
\text { ethanol }\end{array}$ & $\begin{array}{l}\text { partially soluble in } \\
\text { water and practically } \\
\text { insoluble in ethanol }\end{array}$ \\
\hline
\end{tabular}

Table 2 PH examination on toothpaste preparations

\begin{tabular}{|l|c|c|c|c|c|}
\hline & \multicolumn{5}{|c|}{ Days } \\
\cline { 2 - 6 } & 0 & 7 & 14 & 21 & 28 \\
\hline Control & 7.35 & 7.41 & 7.32 & 7.35 & 7.36 \\
\hline Formula 1 & 7.39 & 7.39 & 7.39 & 7.37 & 7.36 \\
\hline Formula 2 & 7.35 & 7.33 & 7.35 & 7.35 & 7.36 \\
\hline Formula 3 & 7.41 & 7.32 & 7.37 & 7.38 & 7.39 \\
\hline
\end{tabular}


Table 3 Viscosity examination on toothpaste preparation

\begin{tabular}{|l|c|c|c|c|c|}
\hline \multirow{2}{*}{} & \multicolumn{5}{|c|}{ Days } \\
\cline { 2 - 6 } & 0 & 7 & 7 & 7 & 7 \\
\hline Control & 579921 & 593013 & 668589 & 678034 & 691041 \\
\hline Formula 1 & 283890 & 280665 & 295110 & 315060 & 334575 \\
\hline Formula 2 & 288050 & 280610 & 309165 & 305150 & 311665 \\
\hline Formula 3 & 283450 & 283905 & 283300 & 283445 & 311060 \\
\hline
\end{tabular}

Note: In centipoise

Table 4 Examination result on preparation of the toothpaste foam height

\begin{tabular}{|l|c|c|c|c|c|}
\hline & \multicolumn{5}{|c|}{ Days } \\
\cline { 2 - 6 } & 0 & 7 & 14 & 21 & 28 \\
\hline Control & 53 & 50 & 52 & 51 & 55 \\
\hline Formula 1 & 52 & 57 & 54 & 55 & 56 \\
\hline Formula 2 & 55 & 52 & 53 & 54 & 55 \\
\hline Formula 3 & 55 & 55 & 53 & 55 & 53 \\
\hline
\end{tabular}

Note: In millimeters

Table 5 Homogeneity examination on toothpaste preparations

\begin{tabular}{|l|c|c|c|c|c|}
\hline \multirow{2}{*}{} & \multicolumn{5}{|c|}{ Days } \\
\cline { 2 - 6 } & 0 & 7 & 14 & 21 & 28 \\
\hline Control & $\mathrm{H}$ & $\mathrm{H}$ & $\mathrm{H}$ & $\mathrm{H}$ & $\mathrm{H}$ \\
\hline Formula 1 & $\mathrm{H}$ & $\mathrm{H}$ & $\mathrm{H}$ & $\mathrm{H}$ & $\mathrm{H}$ \\
\hline Formula 2 & $\mathrm{H}$ & $\mathrm{H}$ & $\mathrm{H}$ & $\mathrm{H}$ & $\mathrm{H}$ \\
\hline Formula 3 & $\mathrm{H}$ & $\mathrm{H}$ & $\mathrm{H}$ & $\mathrm{H}$ & $\mathrm{H}$ \\
\hline
\end{tabular}

Note: $\mathrm{H}=$ Homogeneous, $\mathrm{NH}=$ Not Homogeneous

Table 6 Examination results of color, odor, and flavor of toothpaste

\begin{tabular}{|l|c|c|c|c|c|c|}
\hline & \multicolumn{2}{|c|}{ Color } & \multicolumn{2}{c|}{ Odor } & \multicolumn{2}{c|}{ Taste } \\
\hline & Unchanged & Changed & unchanged & Changed & Good & Awful \\
\hline Controls & $100 \%$ & $0 \%$ & $100 \%$ & $0 \%$ & $100 \%$ & 0 \\
\hline Formula 1 & $100 \%$ & $0 \%$ & $100 \%$ & $0 \%$ & $100 \%$ & 0 \\
\hline Formula 2 & $86.67 \%$ & $13.33 \%$ & $100 \%$ & $0 \%$ & $100 \%$ & 0 \\
\hline Formula 3 & $100 \%$ & $0 \%$ & $100 \%$ & $0 \%$ & $100 \%$ & 0 \\
\hline
\end{tabular}

Table 7 Examination scores of plaque after using toothpaste

\begin{tabular}{|l|c|c|}
\hline Volunteer Group & Deuteronomy & average Difference Score Plaque \\
\hline Formula 1 & 5 & $1.54800 \pm 0.310628$ \\
\hline Formula 2 & 5 & $0.262019 \pm 1.67060$ \\
\hline Formula 3 & 5 & $1.41520 \pm 0.404454$ \\
\hline Control 1 (Base) & 5 & $0.55400 \pm 0.239330$ \\
\hline Control 2 (Commercial Toothpaste ) & 5 & $2.34060 \pm 0.657908$ \\
\hline
\end{tabular}

Table 8 Test results of Post Hoc Bonferroni Score average difference after using the plaque toothpaste

\begin{tabular}{|l|c|c|}
\hline Inter-group & the & Specification \\
\hline Formula 1 - Formula 2 & 1.000 & Not significant \\
\hline Formula 1 - Formula 3 & 1.000 & Not significant \\
\hline Formula 1 - Control 1 & 0.001 & Significant \\
\hline Formula 1 - Control 2 & 0.012 & Significant \\
\hline Formula 2 - Formula 3 & 1.000 & Not significant \\
\hline Formula 2 - Control 1 & 0.000 & Significant \\
\hline Formula 2 - Control 2 & 0.045 & Significant \\
\hline Formula 3 - Control 1 & 0.005 & Significant \\
\hline Formula 3 - Control 2 & 0.003 & Significant \\
\hline Control 1- Control 2 & 0.000 & Significant \\
\hline
\end{tabular}




\section{Discussion}

From the results, it can be shown that the waste of quin pineapple varieties can produce bromelain at $0.238 \%$ yield with good quality and can be used as antiplaque toothpaste. Meanwhile, crude papain from papaya fruit yield obtained a return of $10.15 \%$. Both of these materials are then used as the active ingredient in the preparation of antiplaque toothpaste then tested their physical stability for 28 days and examined the effectiveness of their antiplaque on 25 volunteers.

During the 28 days of preparation, toothpaste showed a relatively stable $\mathrm{pH}$ with a $\mathrm{pH}$ range for all dosage between 7.32 to 7.41 . PH requirements according to ISO 12-3524 for toothpaste in 1995 is 4.5 to 10.5 . Judging from the $\mathrm{pH}$ stability of the active substance, bromelain is stable at $\mathrm{pH} 6$ to 8 and papain is stable at $\mathrm{pH} 6$ to 7 . These results show that the toothpaste containing bromelain and papain was stable regarding $\mathrm{pH}$ formulation.

On examination, there are differences in viscosity between the viscosity of the base with a toothpaste containing bromelain and papain. Cp viscosity base ranges are from 579921 to $691041 \mathrm{cp}$, while toothpaste is holding bromelain and papain range from 288050 to $344575 \mathrm{cp}$. This viscosity difference is because of the nature of bromelain and papain as a proteolytic likely to affect the viscosity of the gelling agent in the preparation of toothpaste. However, the viscosity of the stocks still meet the requirements.

Height measurement of toothpaste foam on the dosage necessary to measure work on the formula is a surface active agent which helps toothpaste release dental plaque. The observation for 28 days showed the resulting foam height ranges from 50 to $57 \mathrm{~mm}$ where the optimum foam height is 55 $\mathrm{mm}$. Examination of the homogeneity of the preparation for 28 days showed that the preparations remain homogeneous did not exhibit growth characteristics of particles or the separation of the active substances of the preparation. It is strongly associated with the stability of the $\mathrm{pH}$ because the $\mathrm{pH}$ changes are likely to cause a shift thickness of gelling agent in the preparation of toothpaste.
On examination of color, smell and taste after 28 days were carried out by 30 respondents showed that respondents said no changes in color and aroma while the taste of toothpaste on average says terrible. Examination of the effectiveness of the antiplaque toothpaste containing a combination of bromelain and papain was conducted on 25 volunteers who have been briefed on this study and already signed informed consent.Volunteers were randomly divided into five groups where each group is using toothpaste that contains bromelain and papain with different degrees and control groups are each using a tube of toothpaste without active substance and commercial toothpaste. The use of toothpaste lasts for a week.

The results of the analysis with ANOVA statistical test showed that there were significant differences ( $\mathrm{p}<0.05$ ) between the average difference of plaque score group using toothpaste that contains bromelain and papain with an average score of plaque groups using commercial toothpaste. Difference in the group of plaque score of F1, $1.54800 \pm 0.310628, \mathrm{~F} 2$ of $1.67060 \pm 0.262019$ and F3 at $1.41520 \pm 0.404454$, Control 1 (basis) $0.55400 \pm$ 0,239330dan Control 2 (commercial toothpaste ) is $2.34060 \pm 0.657908$. But after test multicomparison (Posthoc Test), the result showed that the average difference in plaque score group of F1, F2, and F3 respectively showed no significant differences with an average difference of plaque score group $\mathrm{C} 1$ and $\mathrm{C} 2$.

This shows that the use of waste pineapple bromelain and papain papaya in toothpaste is proven effective as antiplaque. Bromelain as antiplaque has been demonstrated by Harmely, Lucida and Mukhtar (2011) which states that bromelain $5 \%$ of toothpaste showed antiplaque effectiveness. While papain with high levels of $0.1 \%$ and $0.2 \%$ in the mouthwash can reduce the number of colonies of bacteria Streptococcus $\alpha$ but can not reduce the growth of plaque in children aged 13 to 15 years (Waluyatrie, 2012). Therefore papain, in toothpaste antiplaque in commercial products are used with the levels of 1\%. The absence of significance between F1 with 
bromelain concentration of $4 \%$ and $1 \%$ papain, bromelain F2 grading $4.25 \%$ and $0.75 \%$ papain and bromelain $\mathrm{F} 3$ ranking $4.5 \%$ and $5 \%$ papain presumably because of testing time is too short. According to Ariningrum (2000), plaque reduction process is also affected by the frequency, duration and brushing teeth. In general, the group of F2 using toothpaste that contains bromelain and papain $4.25 \%, 0.75 \%$ showed an average difference of the most significant plaque score is $1.67060 \pm 0.262019$. Although third-formula still showed smaller effect than the trademarked toothpaste, toothpaste with bromelain and papain also shows the effect of whitening or bleaching of teeth proved with volunteers teeth look whiter than ever.

The combination of bromelain and papain, in toothpaste, is a combination of synergistic antiplaque of the active ingredient. Both of these materials will decompose pellicle layer composed of a thin layer of protein that covers the tooth enamel without the removal of yellowish color and a high erosion. So the combination of bromelain and papain in addition to functioning as antiplaque also act as a whitening or teeth whitening work safely and naturally.

Based on the data and the above discussion shows that the combination of coarse waste bromelain pineapple (Ananascomosus L. Merr var Quin) and papain (Carica papaya $L$ ) with a ratio of $4 \%$ : $1 \%$, 4.25\%: $0.75 \%$ and $4,5 \%, 0.5 \%$ affect the effectiveness of anti-plaque toothpaste is not in a linear manner. Increased levels of bromelain do not always increase the difference in plaque scores. Instead of decreasing the levels of papain neither does reduce the difference in plaque scores. Optimal results obtained in comparison bromelain and papain 4.25\%: $0.75 \%$ although statistically, inter-comparisons showed no significant differences. The investigators suggest that further research needs to be done on a long time to prove that the combination of bromelain and papain content of $4.25 \%$ and $0.75 \%$ in toothpaste can serve as an antiplaque and natural teeth whitening. With these data, it can be recommended to the pharmaceutical industry for the manufacture of toothpaste by using bromelain from pineapple waste quin variety of sources and papain from papaya fruit.

\section{Conclusions}

1) The physical stability of the preparation of toothpaste which contains a combination of waste bromelain pineapple (Ananascomosus L. Merr var Quin) and papaya(Carica papaya L) meets the requirements of $\mathrm{pH}$, viscosity, homogeneity, the height of foam, color, smell and most importantly it does not irritate the skin.

2) The ability of the combination of coarse waste bromelain pineapple and papaya in affecting the anti-plaque toothpaste is not linear when observing from the difference in plaque scores which increased from a group of F1 $1.54800 \pm 0.310628$ to $\mathrm{F} 2$ of $1.67060 \pm 0.262019$ but decreased in the F3 by $1.41520 \pm 0.404454$.

3) The most effective levels of the combination of a waste of bromelain pineapple and papaya are at $4.25 \%$ and $0.75 \%$.

\section{References}

1. Cherlena, A. Girinda, Rifani, 2009. Aktivitas Bromelain pada Limbah Padat Pengalengan Nenas dan Pengaruh Semipurifikasi. Prosiding Seminar Nasional Teknologi Pengelolaan Limbah IX. BATAN. Fakultas Teknik Universitas Sultan Ageng Tirtayasa. Bogor.

2. Dalimunthe S.H., 2008. Periodonsia. Fakultas Kedokteran Gigi Universitas Sumatera Utara. Medan.

3. Diapari D., 1997. Studi Degradasi Enzim Bromelin dalam Rumen Ternak Domba.Tesis Program Studi Ilmu Ternak PPS IPB. Bogor.

4. Harmely F., H. Lucida, M.H. Mukhtar, 2011. Efektivitas Bromelin Kasar dari Batang Nenas (Ananas comosus L. Merr) Sebagai Anti Plak dalam Pasta Gigi, Scientia Jurnal Farmasi dan Kesehatan. 
Volume 1. Nomor 1. Februari 2011. Stifi Yayasan Perintis Padang.

5. Lopes, A. 2007. Effect of a Papain Based Gel for Chemomechanical Caries Removal on Dentin Shear Bond Strength. J Dent Child (Chic)

6. Rahmadini YP, 2013. Pemanfaatan Bromelin Kasar Dari Bonggol Nanas (Ananas comosus L.Merr) Sebagai Pasta Gigi dan Uji Kestabilan Fisiknya. KTI Jurusan Farmasi Poltekkes Palembang.

7. Waluyatrie E.M., 2011. Pengaruh Berkumur Larutan Enzim Papain 0,1\% dan 0,2\% terhadap Koloni Bakteri Streptococcus $\alpha$ dan Pertumbuhan Plak Gigi pada Anak Perempuan Usia 13-15 Tahun. Tesis PS IKGK. FKG UGM. Yokyakarta.

8. Winarno F.G., 1997. Kimia pangan dan Gizi. Gramedia Pustaka Utama. Jakarta. 